\title{
The nac (Nitrogen Assimilation Control) Gene from Escherichia coli
}

\author{
WILSON B. MUSE AND ROBERT A. BENDER* \\ Department of Biology, The University of Michigan, Ann Arbor, Michigan 48109-1048
}

\begin{abstract}
The nitrogen assimilation control gene, nac, was detected in Escherichia coli but not in Salmonella typhimurium by Southern blotting, using a probe from the Klebsiella aerogenes nac $\left(\right.$ nac $\left._{K}\right)$ gene. The $E$. coli nac gene

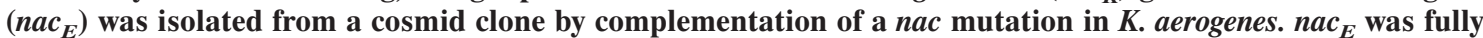
functional in this complementation assay. DNA sequence analysis showed considerable divergence between $n a c_{E}$ and $n a c_{K}$, with a predicted amino acid sequence identity of only $79 \%$ and most of the divergence in the $\mathrm{C}$-terminal half of the protein sequence. The total predicted size of $\mathrm{NAC}_{E}$ is 305 amino acids, the same as for $\mathrm{NAC}_{\mathrm{K}}$. A null mutation, $n a c-28$, was generated by reverse genetics. Mutants bearing $n a c-28$ have a variety of phenotypes related to nitrogen metabolism, including slower growth on cytosine, faster growth on arginine, and suppression of the failure of an Ntr-constitutive mutant to grow with serine as sole nitrogen source. In addition to a loss of nitrogen regulation of histidase formation, $n a c-28$ mutants also showed a loss of a weak repression of glutamate dehydrogenase formation. This repression was unexpected because it is balanced by a NACindependent activation of glutamate dehydrogenase formation during nitrogen-limited growth. Attempts to purify $\mathrm{NAC}_{\mathrm{E}}$ by using methods established for $\mathrm{NAC}_{\mathrm{K}}$ failed, and $\mathrm{NAC}_{\mathrm{E}}$ appears to be degraded with a half-life at $30^{\circ} \mathrm{C}$ as short as 15 min during inhibition of protein synthesis.
\end{abstract}

The nitrogen assimilation control protein (NAC) of Klebsiella aerogenes plays an important role in regulating the nitrogen metabolism of this enteric bacterium $(4,25,40)$. NAC allows the coupling of operons transcribed by RNA polymerase carrying $\sigma^{70}$ to the nitrogen regulatory (Ntr) system (26), which uses RNA polymerase carrying $\sigma^{54}$. In brief, nitrogenlimited growth leads to a starvation for glutamine. Through a complex cascade of events, glutamine starvation leads to phosphorylation (and activation) of the transcriptional regulator NtrC. Phosphorylated NtrC activates RNA polymerase carrying $\sigma^{54}$ to transcribe a number of genes, one of which is nac, which codes for NAC. NAC in turn activates RNA polymerase carrying $\sigma^{70}$ to transcribe a number of operons whose products can supply the cell with ammonium or glutamate from alternative organic sources (4). NAC also represses operons whose function is to assimilate ammonium when ammonium is present in abundance (4). The operons activated by NAC in $K$. aerogenes include hut $U H$, putP, and ureDABCEFG, which code for enzymes required for the catabolism of histidine, proline, and urea, respectively. The operons repressed by NAC include gdhA (glutamate dehydrogenase [GDH]), gltBD (glutamate synthase), and nac itself $(4,16,25)$.

Using the hutUH operon as a model system, we have learned that NAC is both necessary and sufficient to activate transcription from a $\sigma^{70}$-dependent promoter, that no coeffector is needed for NAC's activity, and that a NAC-binding site placed at -64 relative to the start of transcription can activate RNA polymerase even at the lac $Z$ promoter $(19,36,40)$. NAC is a member of the LysR family of transcriptional regulators (41), which includes over 50 members. NAC is a typical member of this family, with two differences: NAC does not require a coeffector for its actions, and the nac gene is not divergently transcribed from an operon that it regulates.

Although NAC plays an important role in the nitrogen regulation of $K$. aerogenes, Salmonella typhimurium appears to

* Corresponding author. Mailing address: Department of Biology, The University of Michigan, Ann Arbor, MI 48109-1048. Phone: (313) 936-2530. Fax: (313) 647-0884. E-mail: rbender@umich.edu. lack a functional nac gene. The hutUH operon of $S$. typhimurium does not respond to nitrogen starvation unless it is moved to a $K$. aerogenes cytoplasm (34) or unless a $\mathrm{nac}^{+}$ plasmid from $K$. aerogenes is present in S. typhimurium (6).

The existence of a nac gene in Escherichia coli K-12 has remained an open question. Many of the NAC-regulated operons of $K$. aerogenes either are absent from $E$. coli (hut and ure) or do not respond to nitrogen regulation (put and $g d h)(45)$. When the hutUH operon from $K$. aerogenes (or S. typhimurium) was transferred to an $E$. coli cytoplasm, hutUH expression was nitrogen regulated but the degree of that regulation was much less than is seen in $K$. aerogenes (18). In other words, the fact that hutUH shows some nitrogen regulation in $E$. coli suggests the presence of an active nac gene, but the weakness of that regulation and the lack of NAC-regulated targets is suggestive of the absence of an active nac gene. The data presented here show that $S$. typhimurium does indeed lack a nac gene and that $E$. coli has a nac gene that is a fully functional analog of the nac gene from $K$. aerogenes.

\section{MATERIALS AND METHODS}

Strains and plasmids. All $K$. aerogenes and E. coli strains used in this study are derived from W70 and K-12 respectively, and are listed in Table 1.

Media and chemicals. Strains were grown in W4 salts (W salts adjusted to an initial $\mathrm{pH}$ of 7.4 [25]) supplemented with carbon and nitrogen sources at 0.4 and $0.2 \%$ (wt/vol), respectively, or in rich LB medium (29). TB medium (44) was used for plasmid isolation. Media for plasmid-bearing strains were supplemented with ampicillin $(100 \mu \mathrm{g} / \mathrm{ml})$, kanamycin sulfate $(50 \mu \mathrm{g} / \mathrm{ml})$, or tetracycline $(25 \mu \mathrm{g} / \mathrm{ml})$ as indicated. Glutamine was always Calbiochem A grade. IPTG (isopropyl- $\beta-\mathrm{D}-$ thiogalactopyranoside) was from Sigma Chemical Company. Sequencing reagents (Sequenase) were from United States Biochemicals, and $\left[\alpha-{ }^{32} \mathrm{P}\right] \mathrm{dATP}$ at $3,000 \mathrm{Ci} / \mathrm{mmol}$ was from ICN Pharmaceuticals.

Genetic techniques. Recombinant DNA techniques were carried out essentially as described by Maniatis et al. (27). DNA was often purified by separating digested DNA fragments in agarose buffered with TAE (27) buffer and then recovering fragments by use of glass resin or by electroelution and precipitation with ethanol. Plasmid constructs were often passed through E. coli DH5 $\alpha$ as a host, and in all cases, only secondary transformants were studied. Strains were made competent for transformation by treatment with calcium chloride (30). Transduction using phage P1vir was performed as described previously (17).

DNA sequence analysis. DNA nucleotide sequence was determined by the chain-terminating method, using modified T7 DNA polymerase (Sequenase) on double-stranded templates, with the following modifications to the protocol 
TABLE 1. Strains and plasmids used

\begin{tabular}{|c|c|c|}
\hline Strain & Relevant characteristics & Source or reference \\
\hline \multicolumn{3}{|l|}{ E. coli } \\
\hline DPB271 & $\mathrm{F}^{-} \lambda^{-}$recD1903::Tn10dTet & Stan Maloy \\
\hline EB3048 & $\operatorname{glnL} 302$ hutC515 ${ }_{K}^{a}$ nac-10 & $\mathrm{P} 1 \cdot \mathrm{EB} 3044 \times \mathrm{YMC} 15$ \\
\hline EB3044 & recD1903::Tn10dTet nac-10 & This study \\
\hline $\mathrm{EB} 3046^{c}$ & hutC $515_{K}$ nac-10 & $\mathrm{P} 1 \cdot \mathrm{EB} 3044 \times \mathrm{YMC} 10$ \\
\hline EB3095 & recD1903::Tn10dTet nac-28 & This study \\
\hline EB3099 & glnL302 hutC515 & P1 $\cdot$ EB3095 $\times$ YMC15 \\
\hline EB3364 & nac-28 & $\mathrm{P} 1 \cdot \mathrm{EB} 3095 \times \mathrm{W} 3110$ \\
\hline EB3365 & hutC515 ${ }_{K}$ nac-28 & P1 $\cdot$ EB3099 $\times$ YMC10 \\
\hline EB4457 & YMC10/pCB1056 & Transformation \\
\hline EB4458 & YMC10/pCB1057 & Transformation \\
\hline EB3846 & W3110/pPC36 & 21 \\
\hline EB4459 & EB3365/pCB1056 & Transformation \\
\hline EB4460 & EB3365/pCB1057 & Transformation \\
\hline W3110 & Wild type & R. Matthews \\
\hline YMC10 & hutC $515_{K}$ & 2 \\
\hline YMC15 & $\operatorname{glnL} 302^{b}$ hutC $515_{K}$ & 9 \\
\hline \multicolumn{3}{|l|}{ K. aerogenes } \\
\hline KC 2914 & KC2330/pTROY11 & Transformation \\
\hline KC2330 & hutC515 galK6 & This laboratory \\
\hline KC2668 & hutC515 $\Delta[$ bla $]-2$ & This laboratory \\
\hline KC2725 & hutC515 nac203::Tn5-131 d $\Delta[$ bla $]-2$ & This laboratory \\
\hline KC2937 & KC2914 (גpgal8) & Lysogen \\
\hline KC2939 & $\operatorname{KC} 2941\left(\lambda 347 \mathrm{Km}^{\mathrm{r}}\right)^{e}$ & Dilysogen \\
\hline KC2941 & KC2937 nac-203::Tn5-131 & Transduction \\
\hline KC2972 & KC2941/pCB511 & Transformation \\
\hline KC3367 & $\mathrm{KC} 2941\left(\lambda 345 \mathrm{Km}^{\mathrm{r}}\right)^{e}$ & Dilysogen \\
\hline \multicolumn{3}{|l|}{ Plasmids } \\
\hline pBGS9 & High-copy-number vector, $\mathrm{Km}^{\mathrm{r}}$ & 43 \\
\hline pCB511 & E. coli nac on a BamHI-to-HindIII fragment subcloned in pGB2 & This study (see Fig. 2) \\
\hline pCB524 & E. coli nac on a BamHI-to-HindIII fragment subcloned in pBGS9 & This study (see Fig. 2) \\
\hline pCB529 & $\mathrm{Km}^{\mathrm{r}}$ cartridge from pWW97 cloned into BglII site of pCB511 & This study (see Fig. 2) \\
\hline pCB547 & pCB529 SacI-to-PvuII deletion & This study (see Fig. 2) \\
\hline pCB552 & nac coding sequence in pJLA503 & This study \\
\hline pCB554 & nac-lacZ fusion in pJLA503 & This study \\
\hline pCB577 & 5.1-kb Bam HI subclone carrying E. coli nac & This study \\
\hline pCB1056 & E. coli nac promoter driving lac $Z$ in $\mathrm{pRJ} 800$ & This study \\
\hline pCB1057 & K. aerogenes nac promoter driving lac Z in $\mathrm{pRJ} 800$ & This study \\
\hline pCJ5 & 2-kb Bam $\mathrm{HI}$ subclone carrying K. aerogenes nac & 6 \\
\hline pGB2 & Low-copy-number vector & 11 \\
\hline pJLA503 & $\lambda p_{\mathrm{L}}$ expression vector & 38 \\
\hline pRJ800 & Promoterless $l a c Z$ reporter & Reid Johnson (33) \\
\hline pRS415 & Promoterless lacZYA reporter & 42 \\
\hline pTROY11 & Plasmid carrying $\lambda$ receptor & Robert Ludwig (12) \\
\hline pWW97 & $\mathrm{Km}^{\mathrm{r}}$ & 31 \\
\hline
\end{tabular}

a The subscript " $K$ " indicates that the hut operons are from $K$. aerogenes. The hutC515 mutation inactivates the hut-specific repressor.

${ }^{b}$ Mutation that makes the strains constitutive for the Ntr system.

${ }^{c}$ P1vir-mediated generalized transduction of strain EB1926 with phage grown on strain EB3044.

${ }^{d} \mathrm{Tn} 5-131$ is a derivative of $\mathrm{Tn} 5$ with the transposase and $\mathrm{Km}^{\mathrm{r}}$ genes replaced by a tetracycline resistance gene (13). Thus, Tn5-131 is $\mathrm{Tnp}^{-}$, Km ${ }^{\mathrm{s}}$, and $\mathrm{Tc}^{\mathrm{r}}$.

${ }^{e} \lambda 347$ and $\lambda 345$ are members of the ordered genomic cosmid library of Kohara et al. (22). $\mathrm{Km}^{\mathrm{r}}$ indicates that a Km ${ }^{\mathrm{r}}$ gene has been added to the phage by the method of Henry and Cronan (20).

supplied by the manufacturer. Strand denaturation by $\mathrm{NaOH}$ was replaced by heat denaturation. The reactions mixture, containing $1 \mu \mathrm{g}$ of plasmid DNA, 50 pmol of primer (usually 17- to 20-bp oligomer), and water to a final volume of 10 $\mu \mathrm{l}$, was heated to $94^{\circ} \mathrm{C}$ for $3 \mathrm{~min}$, followed by quick cooling on ice. Reaction buffer was added after denaturation, and subsequent steps followed the Sequenase protocol. Overlapping sequences were determined for both strands with pCB511 and pCB524 as templates. The sequencing strategy involved primer walking, in which new primers were synthesized by using sequence determined by the results of the previous sequence determination.

Enzyme assays. All assays were performed with cells that had been washed in $1 \% \mathrm{KCl}$ and suspended at a concentration that contained 1 to $1.5 \mathrm{mg}$ of protein per ml. Most assays were performed with cells permeabilized by hexadecyltrimethylammonium bromide. Toluene was used to make cells permeable for proline oxidase assays. Assays for histidase (37), GDH (7), glutamate synthase (28), urease (25), and proline oxidase (37) have been described. Histidase, glutamate synthase, and GDH activities were measured at $37^{\circ} \mathrm{C}$ for historical reasons; all other enzymatic activities were measured at $30^{\circ} \mathrm{C}$. Specific activities are reported as nanomoles of product formed or substrate consumed per minute per milligram of total cell protein. Cell protein was measured by the method of Lowry et al. (24) with bovine serum albumin as the standard, except that whole cells suspended in $1 \% \mathrm{KCl}$ were added directly to the test mixture without prior disruption.

Complementation of $K$. aerogenes nac with genomic clones from $E$. coli. Derivatives of several of the members of the Kohara $E$. coli genomic phage library (22) (miniset 345-348, generously provided by F. Neidhardt) that carried a kanamycin resistance $\left(\mathrm{Km}^{\mathrm{r}}\right)$ gene were isolated as described by Henry and Cronan (20). To insert these derivatives, a $K$. aerogenes host strain required a preexisting $\lambda$ prophage to provide sufficient homology for recombination. Since $K$. aerogenes lacks the $\lambda$ receptor and an att $\lambda$ site, plasmid pTROY11 was used to transform several stains to $\lambda$ sensitivity as described previously (12). To provide a selectable marker for lysogeny, phage $\lambda$ pgal8 (14) (provided by K. McKenny) was used to transduce strain $\mathrm{KC}^{2} 330$ to $\mathrm{Gal}^{+}$. The details of this lysogeny will be 
described elsewhere (35). The resulting $\lambda$ pgal8-containing strains were used as recipients for transduction by derivatized $\left(\mathrm{Km}^{\mathrm{r}}\right)$ Kohara phage $\lambda$ clones.

Southern hybridizations. Chromosomal DNA from E. coli, S. typhimurium, and $K$. aerogenes was prepared from log-phase cultures by using a Puregene DNA isolation kit (Gentra Systems Inc.). Phage DNA from the Kohara miniset members was prepared as described by Chisholm (10). Restriction digests were performed with enzymes supplied by Boehringer Mannheim. DNA fragments were separated by electrophoresis on an $0.8 \%$ agarose gel buffered with Trisborate-EDTA (TBE) and blotted as described by Maniatis et al. (27). Hybridization with probe prepared by random-primed labeling of the 920-bp AfIII fragment from pCJ5 (6) containing the $K$. aerogenes nac gene was performed as described previously (27), varying the hybridization and wash temperatures between 50 and $65^{\circ} \mathrm{C}$.

Mutagenesis of $\boldsymbol{E}$. coli nac. Using the cloned nac gene on plasmid pCB511, we introduced various disruptions into the coding sequence. Initially, a $\mathrm{Km}^{\mathrm{r}}$ gene cartridge from plasmid pWW97 (31) was introduced as a Bam HI fragment into the compatible BglII site internal to nac (see Fig. 2). An amber stop codon linker (SpeI; New England Biolabs) was introduced into the SmaI site present in the cartridge's multiple cloning site (just $3^{\prime}$ to the now destroyed BglII site) to create plasmid pCB529. This plasmid produces a truncated NAC of 169 amino acids, 165 amino acids from NAC and 4 amino acids provided by the multiple cloning site from the $B g l$ II site to the stop codon. This construct was used to make the nac-10 allele. A further and more complete disruption was made by deleting the region between the $\mathrm{SacI}$ and $P v u \mathrm{II}$ sites of this plasmid to delete the promoter and $5^{\prime}$ end ( $\mathrm{N}$ terminus) of the nac gene. This construct, on plasmid pCB547, was nac-28. Replacement of the chromosomal $n a c$ gene with the disrupted gene was achieved following electroporation of linearized plasmid DNA into a recD strain of E. coli (32). These $\mathrm{Km}^{\mathrm{r}}$ tagged nac alleles were immediately transferred into stable host backgrounds by P1vir-mediated transduction of various $E$. coli host strains.

Mobility shift retardation assays. Mobility shift assays were performed with purified $K$. aerogenes NAC protein. Pure NAC protein was isolated as described by Goss and Bender (19). DNA targets were prepared by digestion and precipitation followed by resuspension in Tris-EDTA (TE). Radioactively labeled targets were prepared by filling in the overhanging $5^{\prime}$ ends with $\left[\alpha-{ }^{32} \mathrm{P}\right] \mathrm{dATP}$ (ICN Pharmaceuticals) and the Klenow fragment of DNA polymerase I. Reaction mixtures contained $1 \mu \mathrm{l}$ of DNA, $1 \mu \mathrm{l}$ of poly(dI-dC) $(50 \mathrm{ng} / \mu \mathrm{l}), 4 \mu \mathrm{l}$ of double-distilled $\mathrm{H}_{2} \mathrm{O}$, and $1 \mu \mathrm{NAC}$ dilution in dilution buffer $(50 \mathrm{mM} \mathrm{NaPO}$ [pH 7], $125 \mathrm{mM} \mathrm{NaCl}, 0.5 \mathrm{mM} \mathrm{MgCl}, 0.1 \mathrm{mM} \beta$-mercaptoethanol, $50 \%$ glycerol, $1 \mathrm{mg}$ of bovine serum albumin $/ \mu \mathrm{l}$ ). Reaction mixtures contained dilutions of NAC with 1 to $200 \mathrm{ng}$ of protein/ $\mu \mathrm{l}$ and were allowed to incubate with the DNA for $30 \mathrm{~min}$ before $1.5 \mu \mathrm{l}$ of loading buffer ( $40 \mathrm{mM}$ Tris [pH 8.4], $4 \mathrm{mM}$ EDTA, $0.2 \%$ bromothymol blue, $0.2 \%$ xylene cyanol, $15 \%$ Ficoll) was added and the mixture was loaded for electrophoresis onto $4 \%$ acrylamide gels buffered with TE or $2 \%$ agarose gels with TBE.

Primer extension assays. Primer extension analysis was carried out as described by Ausubel et al. (1), with the following modifications: RNA was purified from log-phase cultures grown in rich broth (LB) or in W4 salts medium supplemented with $0.4 \%$ glucose and $0.2 \%$ L-arginine as the sole nitrogen source (ammonia limiting) or $0.2 \%$ ammonium sulfate plus $0.2 \%$ glutamine (ammonia excess). A template of $25 \mu \mathrm{g}$ of total RNA was used in each reaction. A modified reverse transcriptase (Superscript II) was used in the extension reaction at $52^{\circ} \mathrm{C}$. Reactions were loaded alongside DNA sequencing reactions on a $0.8 \%$ sequencing gel. The same primer was used for primer extension and for sequencing.

Expression of the $\boldsymbol{E}$. coli NAC protein. Initial expression of the E. coli NAC protein was carried out by putting the nac gene under the control of a temperatureinducible promoter in the expression vector pJLA503 (38). This construct, pCB552, was made by PCR amplification of nac from pCB511. Plasmid pCB554 was made by cloning the $\beta$-galactosidase gene from pRS415 into the EcoRI and SalI sites of pCB552 such that lac $Z$ would be transcriptionally fused to $n a c$ and thus coexpressed when the promoter was induced by raising the temperature above $35^{\circ} \mathrm{C}$.

SDS-PAGE analysis of expressed protein. Sodium dodecyl sulfate-polyacrylamide gel electrophoresis (SDS-PAGE) analysis of whole-cell extracts was carried out as described by Ausubel et al. (1), using a polyacrylamide concentration of either $10,12.5$, or $15 \%$.

To determine the half-life of overexpressed NAC protein relative to $\beta$-galactosidase, E. coli DH5 $\alpha$ bearing plasmid pCB554 was induced by shifting growth from 30 to $45^{\circ} \mathrm{C}$ for $40 \mathrm{~min}$ when the culture reached 50 Klett units (green filter). Cells were allowed to grow at this temperature for $1 \mathrm{~h}$, at which time chloramphenicol and rifampin were added to 100 and $50 \mu \mathrm{g} / \mathrm{ml}$, respectively, along with reduction of the growth temperature to $30^{\circ} \mathrm{C}$. Samples $(0.2 \mathrm{ml})$ were taken every $5 \mathrm{~min}$ from the culture flask and placed immediately on ice. Cells were collected by centrifugation at $4^{\circ} \mathrm{C}$ and resuspended in $20 \mu \mathrm{l}$ of TE; $10 \mu \mathrm{l}$ of each sample was loaded on an SDS-gel for PAGE.

Nucleotide sequence accession number. The DNA sequence has been deposited in GenBank with accession no. U56736.

\section{RESULTS}

E. coli carries a functional nac gene. Interspecies complementation has suggested that $E$. coli expresses a functional NAC but $S$. typhimurium does not $(6,18)$. To test whether $E$. $\begin{array}{llllllll}1 & 2 & 3 & 4 & 5 & 6 & 7 & 8\end{array}$

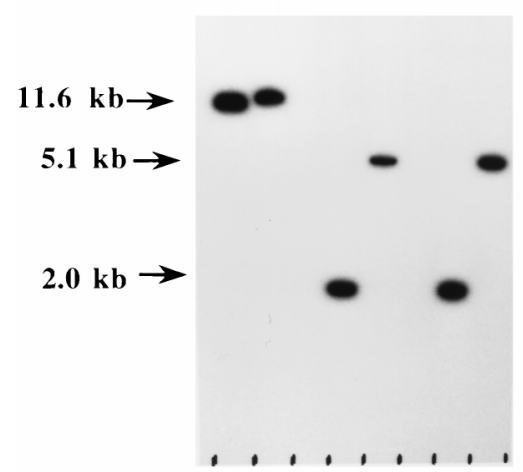

FIG. 1. Southern blot of digested chromosomal DNA probed with a 920-bp AflII fragment (carrying the $K$. aerogenes nac gene). Lanes 1 to 3 and 4 to $6, K$. aerogenes, E. coli, and $S$. typhimurium, respectively, digested with EcoRI (lanes 1 to 3 ) and BamHI (lanes 4 to 6); lanes 7 and 8, K. aerogenes and E. coli plasmid clones (pCJ5 and pCB577, respectively) digested with BamHI.

coli and S. typhimurium possess a homolog of the $K$. aerogenes $n a c$ gene, we looked for hybridization between the $K$. aerogenes $n a c$ gene and DNA from these organisms. DNA from $K$. aerogenes W70 (strain KC1043), E. coli K-12 (strain W3110), and S. typhimurium 15-59 (strain NE7) was digested with EcoRI or with BamHI. After separation of the resulting fragments by agarose gel electrophoresis, a hybridization analysis by the method of Southern was carried out with an AflII fragment from within the $K$. aerogenes nac gene as probe. Under stringent conditions (hybridization and washes at $65^{\circ} \mathrm{C}$ ), this $920-\mathrm{bp}$ probe hybridized to a single fragment of $K$. aerogenes DNA but did not hybridize to any DNA fragment from $E$. coli or $S$. typhimurium. When the stringency of the hybridization and washes was reduced $\left(58^{\circ} \mathrm{C}\right)$, we detected a single fragment from $E$. coli DNA but no hybridization with $S$. typhimurium DNA (Fig. 1). The positions of the bands suggested that the $E c o$ RI and BamHI fragments from E. coli were about 11.6 and $5.1 \mathrm{~kb}$ in size. When the stringency of the hybridization and washes was reduced still further $\left(50^{\circ} \mathrm{C}\right)$, hybridization to $S$. typhimurium DNA was detected but there were many fragments showing hybridization in the lanes containing DNA from each of the three organisms under these conditions (not shown). Thus, E. coli appears to have a locus with strong sequence similarity to nac from $K$. aerogenes; $S$. typhimurium appears to lack such a sequence.

The genetic maps of $E$. coli and $K$. aerogenes are quite similar in all regions that have been compared (5), so it seemed likely that the nac gene of $E$. coli would lie in a region analogous to that of the nac gene of $K$. aerogenes. Several $\lambda$ clones from the Kohara ordered set of genomic clones (22) were tested for complementation of a nac mutant of $K$. aerogenes. Four clones (345 through 348 ) believed to cover the E. coli chromosomal region analogous to that containing the nac gene in K. aerogenes were chosen and modified to encode kanamycin resistance as described by Henry and Cronan (20). These derivatized phage were then used to transduce a nac-deficient $\lambda$ lysogen of $K$. aerogenes (strain KC2941) to kanamycin resistance. Transductants were assayed for histidase and GDH activities. Only the transductants derived from clones 346 and 347 showed NAC-dependent regulation of histidase and glutamate dehydrogenase formation. As shown in Table 2, the strain carrying the prophage derived from clone 347 showed the same activation of histidase, urease, and proline oxidase in response to nitrogen starvation as the wild type. That strain 
TABLE 2. Regulation of enzyme formation in a K. aerogenes nac mutant carrying the nac gene from E. coli

\begin{tabular}{|c|c|c|c|c|c|c|c|}
\hline \multirow{2}{*}{ Strain } & \multirow{2}{*}{ Relevant genotype } & \multirow{2}{*}{$\begin{array}{l}\text { Growth } \\
\text { medium }^{b}\end{array}$} & \multicolumn{5}{|c|}{ Sp activity (U/mg of protein $)^{a}$} \\
\hline & & & Histidase & GDH & Urease & $\begin{array}{l}\text { Proline } \\
\text { oxidase }\end{array}$ & $\begin{array}{l}\text { Glutamate } \\
\text { synthase }\end{array}$ \\
\hline \multirow[t]{2}{*}{ KC2668 } & Wild type & $+\mathrm{N}$ & 33 & 361 & 11 & 9 & 193 \\
\hline & & $-\mathrm{N}$ & 357 & 52 & 1,380 & 47 & 70 \\
\hline \multirow{2}{*}{ КC2941 } & nac-203::Tn5-131 & $+\mathrm{N}$ & 33 & 379 & 10 & 12 & 260 \\
\hline & & $-\mathrm{N}$ & 51 & 401 & 242 & 17 & 245 \\
\hline \multirow[t]{2}{*}{ KC2939 } & $n a c-203\left(\lambda 347 \mathrm{Km}^{\mathrm{r}}\right)^{c}$ & $+\mathrm{N}$ & 39 & 369 & 15 & 11 & 216 \\
\hline & & $-\mathrm{N}$ & 319 & 94 & 1,212 & 32 & 125 \\
\hline \multirow{2}{*}{ KC3367 } & $n a c-203\left(\lambda 345 \mathrm{Km}^{\mathrm{r}}\right)$ & $+\mathrm{N}$ & 29 & 423 & 21 & 11 & $\mathrm{ND}^{e}$ \\
\hline & & $-\mathrm{N}$ & 54 & 411 & 207 & 13 & ND \\
\hline \multirow{2}{*}{ KC2972 } & $n a c-203 / \mathrm{pCB} 511^{d}$ & $+\mathrm{N}$ & 31 & 292 & 13 & 8 & 232 \\
\hline & & $-\mathrm{N}$ & 460 & 41 & 1,275 & 39 & 98 \\
\hline
\end{tabular}

${ }^{a}$ Average of three independent cultures. Units of urease activity are calculated based on urea cleaved.

${ }^{b}$ Nitrogen-limiting medium $(-\mathrm{N})$ is W4 salts supplemented with glucose $(0.4 \%)$ and $\mathrm{L}$-glutamine $(0.2 \%)$ as sole nitrogen sources. Nitrogen-excess medium $(+\mathrm{N})$ is further supplemented with ammonium sulfate $(0.2 \%)$. Cultures were grown at $30^{\circ} \mathrm{C}$ with vigorous shaking to mid-log phase (50 Klett units). Media for cells used in urease assays were supplemented with $1 \mu \mathrm{M}$ nickel sulfate. Media for cells used in proline oxidase assays were supplemented with $0.01 \%$ L-proline.

${ }^{c} \lambda 347$ carries the $E$. coli nac gene; $\lambda 345$ does not.

${ }^{d}$ Plasmid pCB511 carries the intact $E$. coli nac gene.

${ }^{e} \mathrm{ND}$, not done.

also showed the same NAC-dependent repression of GDH and glutamate synthase as the wild type (compare KC2939 with KC2668). In contrast, a strain carrying the prophage derived from clone 345 was as defective as the nac mutant in activation and repression of enzyme formation in response to nitrogen starvation (compare KC3367 with KC2941). Thus, the nac gene from $E$. coli seems fully able to complement a $K$. aerogenes nac mutant.

The region of overlap between the two complementing clones (346 and 347) includes an EcoRI fragment of about 12 $\mathrm{kb}$ which in turn contains a Bam HI fragment of about $5.4 \mathrm{~kb}$, in close agreement with the sizes predicted from the Southern blot in Fig. 1.

Isolation and characterization of the $E$. coli nac gene. The $E$. coli nac gene was isolated as a 5.4-kb Bam HI fragment from the Kohara miniset clone 347 in both a low-copy-number vector (pGB2) and a high-copy-number vector (pBGS9). Highcopy-number plasmids carrying nac cause the cells that carry them to grow slowly, perhaps because of the high-level expression of the adjacent $a s n V$ gene ( $\left.\mathrm{tRNA}^{\mathrm{Asn}}\right)$. A restriction map of this fragment is shown in Fig. 2.

The sequence of the nac gene and those of the two adjacent genes ( $a s n V$ and $c b l)$ were determined by the dideoxy sequencing method on both strands. The sequence of the E. coli nac promoter region is very different from the corresponding region from the $K$. aerogenes nac gene, except in those regions known to specify the binding of important regulatory proteins, including NAC, NtrC, and RNA polymerase (Fig. 3). The deduced protein sequence of $E$. coli NAC differs considerably from that of $K$. aerogenes, in contrast to the situation with most regulatory proteins, where strong similarity (often approaching
$100 \%$ ) exists. The N-terminal one-third is quite similar (greater than $90 \%$ identity), but the C-terminal two-thirds differs much more than expected (only about $75 \%$ identity). Thus, the overall deduced amino acid sequence identity is about $79 \%$.

Like the K. aerogenes nac gene (41), the E. coli nac gene is preceded by a sequence resembling a $\sigma^{54}$-dependent promoter. The start of transcription was determined by primer extension analysis (Fig. 4) and confirms that the putative $\sigma^{54}$-dependent promoter is in fact the promoter of the E. coli nac gene.

Isolation of nac mutations. Two nac mutations were isolated by reverse genetics, taking advantage of a $\mathrm{BglII}$ site at the $165 \mathrm{th}$ codon of the nac coding sequence and a $P v u$ II site upstream of the nac promoter. The nac-10 mutation is an insertion of a $\mathrm{Km}^{\mathrm{r}}$ cassette from plasmid pWW97 into the BglII site of nac. Such a mutation leads to a truncated NAC with only the N-terminal 165 amino acids of NAC plus 4 amino acids encoded in the linker used to provide a stop codon. The nac- 28 mutation was derived from $n a c-10$ by deletion of the DNA from the PvuII site upstream of the nac promoter to a $S a c$ I site just inside the $\mathrm{Km}^{\mathrm{r}}$ cassette. Thus, nac-28 is a null allele for nac that deletes the nac promoter and the entire N-terminal half of the $n a c$ coding sequence. The nac- 28 mutation was crossed onto the $E$. coli chromosome as described in Materials and Methods, and replacement of the wild-type nac gene was confirmed by Southern blot analysis (not shown). The resulting mutant strains were tested for regulation of the $K$. aerogenes hutUH operon in these E. coli strains (Table 3).

Strains carrying nac-28 were unable to derepress histidase synthesis whether nac expression was induced physiologically (by nitrogen-limited growth of strain EB3365) or genetically

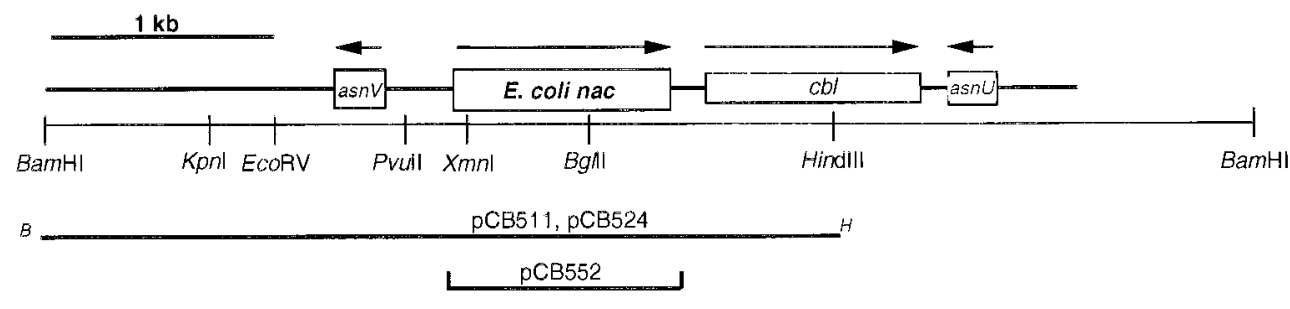

FIG. 2. E. coli nac region and clones. 

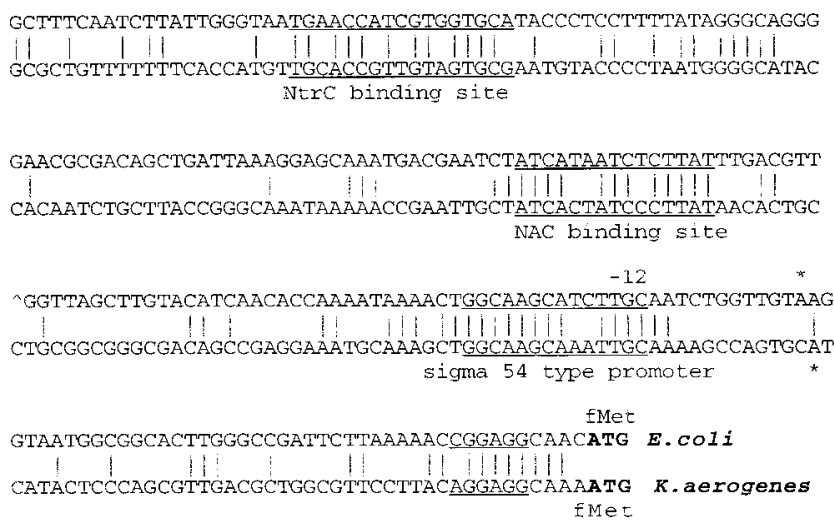

FIG. 3. Comparison of the promoter regions from the nac genes of $E$. coli (top) and $K$. aerogenes (bottom). |, identity; $\wedge$, space added for better alignment; *, start of transcription as determined by primer extension.

(by the $\ln L 302$ mutation in strain EB3099, which makes the Ntr system constitutively active).

The gdhA genes (encoding GDH) from $E$. coli and K. aerogenes are quite similar. In particular, a sequence resembling a NAC-binding site is found at about -80 in the promoter regions of the $g d h A$ genes from both organisms. However, expression of GDH activity in $E$. coli does not vary appreciably in response to nitrogen limitation, in contrast to the strong repression seen in K. aerogenes. Analysis of GDH expression in strains with the nac-28 mutation reveals a subtle regulatory complexity. The nac-28 mutants show about a twofold increase in GDH expression when the Ntr system is activated either by nitrogen limitation or by the glnL302 mutation (strains EB3365 and EB3099 in Table 3). In contrast, the $\mathrm{nac}^{+}$strain YMC10 showed a slight but reproducible repression of GDH expression. Thus, there appears to be an approximately twofold repression of GDH expression in E. coli by NAC, and this is

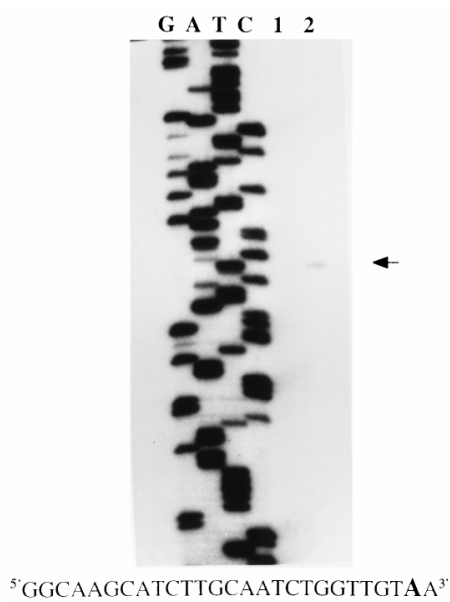

FIG. 4. Primer extension analysis of the E. coli nac promoter. RNA was extracted from YMC10 cells grown in nitrogen-excess medium containing ammonium sulfate $(0.2 \%)$ and glutamine $(0.2 \%)$ as nitrogen sources (lane 1$)$ and from YMC10 cells grown in nitrogen-limiting medium containing arginine $(0.2 \%)$ as the nitrogen source (lane 2). A sequencing ladder was generated by using the nac containing plasmid pCB524 as template. The same oligonucleotide (5' GCTGGTTGTGCGATATGCA 3') was used as a primer for primer extension and for the sequencing reactions; thus, the sequencing ladder represents the complement of the sequence shown. The sequence at the bottom is the $E$. coli nac promoter, with the start of transcription indicated by the bold A.
TABLE 3. Nitrogen regulation of enzyme formation in E. coli nac mutants

\begin{tabular}{llccr}
\hline \multirow{2}{*}{ Strain } & Relevant genotype & $\begin{array}{c}\text { Growth } \\
\text { medium }^{b}\end{array}$ & \multicolumn{2}{c}{$\begin{array}{c}\text { Sp activity (U/mg of } \\
\text { protein })^{a}\end{array}$} \\
\cline { 3 - 5 } & & Histidase & GDH \\
\hline YMC10 & hutC515 $_{K}$ & $+\mathrm{N}$ & 98 & 175 \\
& & $-\mathrm{N}$ & 320 & 145 \\
EB3365 & YMC10 nac-28 & $+\mathrm{N}$ & 96 & 118 \\
& & $-\mathrm{N}$ & 108 & 257 \\
YMC15 & glnL302 hutC515 & $+\mathrm{N}$ & 375 & 86 \\
EB3099 & YMC15 nac-28 & $+\mathrm{N}$ & 145 & 130 \\
W310 & Wild type & $+\mathrm{N}$ & NA & 96 \\
& & $-\mathrm{N}$ & NA & 84 \\
EB3364 & W3110 nac-28 & $+\mathrm{N}$ & NA & 91 \\
& & $-\mathrm{N}$ & NA & 146 \\
\hline
\end{tabular}

\footnotetext{
${ }^{a}$ Average of four independent cultures.
}

${ }^{b}$ Nitrogen-limiting $(-\mathrm{N})$ and nitrogen-excess $(+\mathrm{N})$ indicate growth at $37^{\circ} \mathrm{C}$ in $\mathrm{W} 4$ salts supplemented with glucose $(0.4 \%)$ and either L-arginine $(0.2 \% ;-\mathrm{N})$ or ammonium sulfate $(0.2 \% ;+\mathrm{N})$.

${ }^{c}$ NA, not applicable.

almost exactly balanced by a nearly twofold increase in GDH expression during nitrogen-limited growth by an unknown mechanism. There is considerable variation in the expression of GDH among different $E$. coli strain backgrounds; therefore, we compared a nac-28 mutant of strain W3110 with its $n a c^{+}$ parent and found essentially the same effect as seen with YMC10 (Table 3). Although the regulatory effects of NAC on GDH expression are small, they are physiologically significant. gltD mutants lack glutamate synthase activity, and their assimilation of ammonium is completely dependent on GDH. Strain EB3135 (gltD nac-28) grows faster than EB3134 ( $g l t D)$ in glucose medium with ammonium as the sole nitrogen source (doubling times of $49 \pm 8$ and $65 \pm 10 \mathrm{~min}$ for EB3135 and EB3134, respectively).

Effect of nac mutations on growth rate of $E$. coli. In $K$. aerogenes, nac mutations have no phenotype except slower growth on substrates like histidine, proline, or urea that are catabolized by products of NAC-dependent operons (3). This was also seen in $E$. coli in that nac mutants grew significantly more slowly in glucose minimal medium with cytosine as the sole nitrogen source, with doubling times of $180 \pm 5$ and $235 \pm$ $10 \mathrm{~min}$ for the $\mathrm{nac}^{+}$and nac strains, respectively. The nac mutant also grew somewhat more slowly when either serine or threonine was the sole nitrogen source. This was readily seen as a difference in colony size, but the doubling times of nac mutants on serine or threonine were only about 5 min (about $3 \%$ ) longer than the $\mathrm{nac}^{+}$parent.

In contrast, when nac mutants of $E$. coli were grown on glucose-arginine medium (i.e., glucose minimal medium with L-arginine as the sole nitrogen source [Table 4]) the growth rate actually increased, with doubling times of $147 \pm 3$ and $134 \pm 4$ for the $\mathrm{nac}^{+}$and $n a c$ strains, respectively. The increase was always small but was clearly seen in all five of the paired growth experiments attempted. This difference was particularly large in strains which carry the $\ln L 302$ allele, which leads to constitutive expression of the Ntr system and thus constitutive NAC expression. In addition to an increased growth rate on glucose-arginine medium, there is also a decrease in the growth lag when cells are transferred from nitrogen-rich medium (glucose minimal medium supplemented with $0.2 \%$ ammonium sulfate) to glucose-arginine. The growth rate advantage of the nac mutants was minimized when even small amounts of glutamate $(0.02 \%)$ or aspartate $(0.01 \%)$ were 
TABLE 4. Growth rates of E. coli strains containing nac and $\operatorname{gln} L$ mutations ${ }^{a}$

\begin{tabular}{|c|c|c|c|c|}
\hline Medium & Strain & $\begin{array}{l}\text { Relevant } \\
\text { genotype }\end{array}$ & $\begin{array}{l}\text { Lag } \\
\text { time } \\
(\min )\end{array}$ & $\begin{array}{l}\text { Doubling } \\
\text { time } \\
\text { (min) }\end{array}$ \\
\hline \multicolumn{5}{|l|}{$\begin{array}{l}\text { Glucose }(0.4 \%)- \\
\text { L-arginine }(0.2 \%)\end{array}$} \\
\hline & YMC10 & Wild type & 245 & 147 \\
\hline & YMC15 & $g \ln L 302$ & 225 & 140 \\
\hline & EB3365 & nac- -28 & 196 & 134 \\
\hline & EB3099 & $g \ln L 302$ nac-28 & 152 & 109 \\
\hline \multicolumn{5}{|l|}{$\begin{array}{l}\text { Glucose }(0.4 \%)- \\
\text { L-arginine }(0.2 \%)- \\
\text { glutamate }(0.02 \%)\end{array}$} \\
\hline & YMC10 & Wild type & 198 & 135 \\
\hline & YMC15 & $g \ln L 302$ & 159 & 110 \\
\hline & EB3365 & nac-28 & 193 & 133 \\
\hline & EB3099 & glnL302 nac-28 & 110 & 106 \\
\hline
\end{tabular}

${ }^{a}$ Growth rates were measured at $37^{\circ} \mathrm{C}$ in $\mathrm{W} 4$ medium supplemented as indicated. Lag times were calculated upon shift from log-phase growth on glucose $(0.4 \%)$-ammonia $(0.2 \%)$ cultures to the indicated medium. Cells were washed twice in cold $1 \% \mathrm{KCl}$ before inoculation into new medium. Growth rate was determined by monitoring the cell density of a vigorously shaking culture in sidearm flasks.

added to the glucose-arginine medium (Table 4). Another phenotype involved the ability of a $g \ln L 302$ strain to grow in glucose minimal medium with serine as the sole nitrogen source. Strains carrying the glnL302 mutation failed to grow on glucose-serine medium. The reason for this failure is not known. Nonetheless, nac mutations allow the $g \ln L$ strain to grow in glucose with serine as the sole nitrogen source (as do $g \ln E$ mutations).

Effect of NAC on nac expression in $\boldsymbol{E}$. coli. Transcription of the $K$. aerogenes nac gene is strongly regulated by the $\mathrm{Ntr}$ system in response to the nitrogen supply (25). It is also repressed by the binding of NAC to a site centered about $77 \mathrm{bp}$ upstream from the start of transcription $(6,16)$. When the $K$. aerogenes nac promoter was cloned on a high-copy-number plasmid driving $\beta$-galactosidase expression, the $E$. coli Ntr system was fully functional in regulating transcription from the $K$. aerogenes nac promoter (Table 5, lines 1 and 2 or 3 and 4). The chromosomally encoded NAC exerted a weak repression on $n a c$-driven $\beta$-galactosidase expression from this multicopy plasmid (Table 5, lines 2 and 4). When the E. coli nac promoter replaced that from $K$. aerogenes, a similar regulation in response to the nitrogen supply (Table 5 , lines 5 and 6 or 7 and 8 ), as well as a similar repression by NAC (Table 5, lines 6 and 8 ), was seen. The E. coli nac promoter contains a sequence resembling the NAC-binding site from the $K$. aerogenes nac promoter, and this site is also in a very similar position (centered at -76). A gel mobility shift assay (Fig. 5) confirms that NAC binds to the $E$. coli nac promoter region, consistent with the argument that the $E$. coli nac gene is autogenously regulated, just like that from $K$. aerogenes.

Expression of $\boldsymbol{E}$. coli nac coding sequence. The coding sequence of $E$. coli nac was expressed from a plasmid expression vector with a temperature-inducible phage $\lambda p_{\mathrm{L}}$ promoter (38). SDS-PAGE of expressed NAC showed a protein of $33 \mathrm{kDa}$ as expected from the sequence. Curiously, no NAC protein was seen when strains bearing this construct were grown at $42^{\circ} \mathrm{C}$. To visualize protein, the strains had to be grown at $46^{\circ} \mathrm{C}$. Control experiments using this vector (38) suggested that an ample amount of protein should have been made at $42^{\circ} \mathrm{C}$. To reconcile this discrepancy, a transcriptional fusion was made by placing the lac $Z$ coding sequence immediately downstream of
TABLE 5. Regulation of nac promoter expression by E. coli nac

\begin{tabular}{llcr}
\hline Strain & Relevant genotype $^{a}$ & $\begin{array}{c}\text { Growth } \\
\text { medium }^{b}\end{array}$ & $\begin{array}{c}\beta \text {-Galactosidase } \\
\text { sp act (U/mg) }\end{array}$ \\
\hline EB4458 & Wild type/pCB1057 & $+\mathrm{N}$ & 487 \\
& & $-\mathrm{N}$ & 13,074 \\
EB4460 & nac-28/pCB1057 & $+\mathrm{N}$ & 502 \\
& & $-\mathrm{N}$ & 25,011 \\
EB4457 & Wild type/pCB1056 & $+\mathrm{N}$ & 449 \\
& & $-\mathrm{N}$ & 16,901 \\
EB4459 & nac-28/pCB1056 & $+\mathrm{N}$ & 507 \\
& & $-\mathrm{N}$ & 28,290 \\
\hline
\end{tabular}

${ }^{a}$ Plasmid pCB1056 carried the nac promoter from $E$. coli fused to the promoterless $l a c Z$ gene of pRJ800; pCB1057 carries the nac promoter from $K$. aerogenes fused to the promoterless lac $Z$ gene of pRJ800.

${ }^{b}$ Nitrogen-excess growth medium $(+\mathrm{N})$ is W4 salts supplemented with glucose $(0.4 \%)$, ammonium sulfate $(0.2 \%)$, and L-arginine $(0.2 \%)$. Nitrogen-limiting $(-\mathrm{N})$ medium was supplemented with glucose $(0.4 \%)$ and L-arginine $(0.2 \%)$. Cultures were grown at $37^{\circ} \mathrm{C}$ assayed as described in Materials and Methods.

${ }^{c}$ Average of five independent determinations.

the nac coding sequence, creating an artificial operon with nac and $l a c Z$ cotranscribed. Expressed $\beta$-galactosidase was readily detected at the lower temperatures $\left(37\right.$ and $\left.42^{\circ} \mathrm{C}\right)$, suggesting that both genes were being adequately transcribed. It seemed likely that either the NAC transcript was being inefficiently translated or the NAC protein was being degraded. Therefore, we compared the stabilities of the NAC and $\beta$-galactosidase polypeptides. NAC and $\beta$-galactosidase were produced by growing strains at $46^{\circ} \mathrm{C}$ for $1 \mathrm{~h}$ and then shifting the temperature to $30^{\circ} \mathrm{C}$ along with the addition of chloramphenicol and rifampin to prevent further translation and transcription. The disappearance of the NAC and $\beta$-galactosidase polypeptides was monitored by SDS-PAGE (Fig. 6). The NAC bands exhibited a half-life of about 15 min following overexpression and growth at $30^{\circ} \mathrm{C}$, in contrast to the more stable $\beta$-galactosidase protein (half-life of $>35 \mathrm{~min}$ ).

\section{DISCUSSION}

The data presented here show clearly that E. coli has a functional homolog of the $K$. aerogenes nac gene. DNA sequence analysis of $E$. coli nac (hereafter referred to as $n a c_{E}$ ) predicts a protein with about $80 \%$ identity to the $K$. aerogenes NAC (hereafter referred to as $\mathrm{NAC}_{\mathrm{K}}$ ). Moreover, $n a c_{E}$ is fully able to complement a $K$. aerogenes nac mutant for activation of

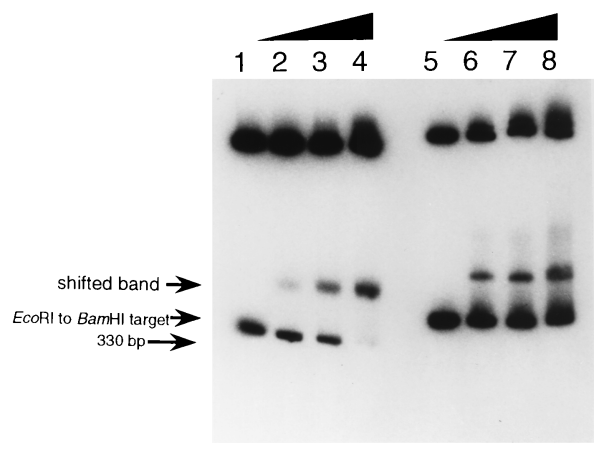

FIG. 5. Gel mobility shift assay showing the interaction of NAC with the $E$. coli nac region. Lanes: 1 to 4, 330-bp Eco RI-HindIII fragment containing the $K$. aerogenes ure $D$ promoter incubated with $0,0.35,0.7,1.7$ pmol of purified $K$. aerogenes NAC, respectively; 5 to 8, 378-bp EcoRI-to-BamHI fragment containing the E. coli nac promoter incubated with $0,0.35,0.7$, and $1.7 \mathrm{pmol}$ of $K$. aerogenes NAC, respectively. 


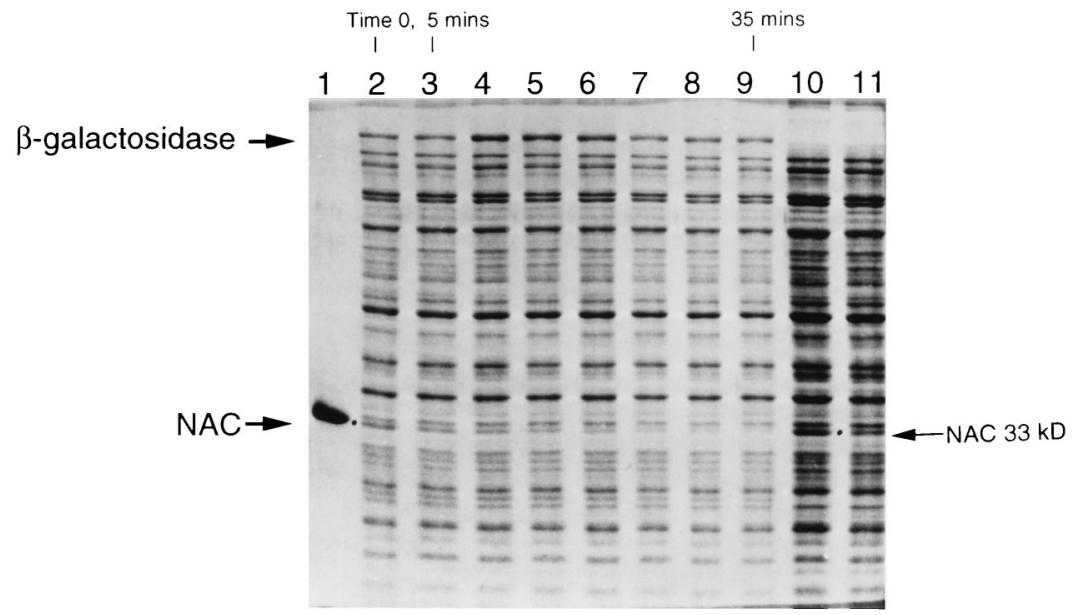

FIG. 6. Relative stabilities of $E$. coli NAC and $\beta$-galactosidase. E. coli NAC and $\beta$-galactosidase were cotranscribed from the temperature-inducible phage $\lambda p_{\mathrm{L}}$ promoter in plasmid pCB554. Cells were grown to a density of approximately 50 Klett units, and expression was induced by growth at $45^{\circ} \mathrm{C}$ for $40 \mathrm{~min}$. At time zero, the culture was shifted to $30^{\circ} \mathrm{C}$ and chloramphenicol and rifampin were added. Samples $(0.2 \mathrm{ml})$ were removed at 5 -min intervals and concentrated 10 -fold, and $10 \mu \mathrm{l}$ was applied to an SDS-12.5\% polyacrylamide gel. Lanes: $1,5 \mu \mathrm{g}$ of $K$. aerogenes NAC as a standard; 2 , sample at time zero; 3 to 9 , samples at 5-min intervals; 10 and 11, E. coli NAC expressed from plasmid pCB552 (which transcribes NAC alone).

hut, put, and ure operon expression as well as for repression of $g d h A$ expression and probably for autogenous repression of $n a c_{K}$ expression. On one hand, the existence of $n a c_{E}$ was not surprising given the close evolutionary relationship between $E$. coli and $K$. aerogenes. On the other hand, we have long known that the operons that NAC regulates in $K$. aerogenes are absent from $E$. coli (hut and ure) or are either unregulated or only slightly regulated by nitrogen in E. coli ( $g d h A$ and put). That raised the question of whether $E$. coli had a nac gene and, if so, what that gene did. We continue to find operons in K. aerogenes with a NAC-dependent regulation, most recently the $\operatorname{dad} A B$ operon which is involved in alanine catabolism (21). Again, dad is NAC regulated in $K$. aerogenes but not in $E$. coli. Nevertheless, it seems likely that as more NAC-regulated operons are discovered, some of them will be NAC regulated in E. coli as well.

Although $\mathrm{NAC}_{\mathrm{E}}$ is a functional homolog of $\mathrm{NAC}_{\mathrm{K}}$, the degree of sequence divergence between $\mathrm{NAC}_{\mathrm{E}}$ and $\mathrm{NAC}_{\mathrm{K}}$ is surprising. Most regulatory proteins are highly conserved between these two bacteria. NtrC and Lrp are identical in the two strains, and catabolite gene activator protein and the $\alpha$ subunit of RNA polymerase differ by only one and two amino acids in these bacteria. Homologous LysR family members also tend to be highly conserved within the enteric bacteria. For example, the CysB proteins from E. coli and S. typhimurium are $95 \%$ identical in amino acid sequence (39). In fact, the entire LysR family shows surprising sequence conservation. NAC from $K$. aerogenes is $50 \%$ identical to OxyR (a regulator that senses oxidative stress) from $E$. coli (41). Thus, the $>20 \%$ nonidentity between $\mathrm{NAC}_{\mathrm{E}}$ and $\mathrm{NAC}_{\mathrm{K}}$ is striking. It should be noted that there is strong sequence conservation in the amino-terminal one-third of the protein and that most of the sequence divergence is found in the carboxy-terminal two-thirds. The carboxy-terminal portion is generally thought to be important for interaction of LysR family proteins with their regulatory coeffectors (39). $\mathrm{NAC}_{\mathrm{K}}$ appears to lack any coeffectors and to be a constitutively active transcriptional regulator (25). This may explain the lack of sequence conservation in this region. However, it must be noted that $\mathrm{NAC}_{\mathrm{E}}$ and $\mathrm{NAC}_{\mathrm{K}}$ both have exactly 305 amino acids and that their length is quite typical of all other LysR family members. Therefore, the carboxy-terminal domain(s) may play some role (such as stability) other than response to a coeffector signal. In support of this argument, we noted that the hydropathy plots of $\mathrm{NAC}_{\mathrm{E}}$ and $\mathrm{NAC}_{\mathrm{K}}$ are remarkably similar, despite the $25 \%$ divergence of the amino acid sequence in the carboxy-terminal region.

The physiological role for $\mathrm{NAC}_{\mathrm{E}}$ remains unproved, though the data presented here suggest that $\mathrm{NAC}_{\mathrm{E}}$, like $\mathrm{NAC}_{\mathrm{K}}$, is involved in regulating the nitrogen metabolism of the cell. Several lines of evidence support this hypothesis. First, the $n a c-28$ mutation affects the growth rate of $E$. coli on a variety of nitrogen sources, including arginine (faster), cytosine (slower), and serine (allowing growth of Ntr-constitutive strains). Second, even though the strong repression of $g d h A$ by NAC seen in $K$. aerogenes does not occur in $E$. coli, a small but significant effect is detectable. In the nac-28 mutant, GDH expression increases about twofold in response to nitrogen limitation. In wild-type strains, this increase does not occur. In a gltB mutant, where glutamate formation from ammonia is completely dependent on GDH, a strain carrying nac- 28 grows faster with ammonium as nitrogen source than does a $\mathrm{nac}^{+}$ strain, suggesting that this twofold effect on GDH expression is important. Third, the key regulatory sites in the $n a c_{K}$ promoter region $(15,16)$ are well conserved, both in sequence and in position, in the $n a c_{E}$ promoter region. These include the $\sigma^{54}$ dependent promoter and the NtrC-binding enhancer sequence. Thus, it is likely that $n a c_{E}$, like $n a c_{K}$, is transcribed as part of the Ntr response during nitrogen limitation.

The absence of any nac-like sequences in S. typhimurium is consistent with older observations that NAC-dependent operons cannot be expressed in response to nitrogen limitation (6, 8). The absence of a nac gene in $S$. typhimurium also raises questions about the evolutionary plasticity of this chromosomal region in the Enterobacteriaceae. The $n a c_{K}$ gene is preceded by asnV, the gene that codes for tRNA ${ }^{\text {Asn }}$, and it is followed by an apparent operon composed of $\operatorname{cblA}$ (orf2), itself a member of the LysR family, and orf3. The function of this operon is unknown but may be related to sulfur metabolism. In E. coli, nac is again preceded by asnV and followed by $c b l A$, but orf 3 is located upstream from $n a c$, on the other side of $a s n V$. In $S$. typhimurium, nac is not present. There is evidence that the $a s n V$ region may be where the large cluster of $c o b$ genes, 
encoding the enzymes of cobalamine synthesis, lies in S. typhimurium (23). (E. coli lacks this cob cluster.) Similarly, the large cluster of nif genes (encoding the enzymes of nitrogen fixation) in K. pneumoniae appear to be linked to nac. (The nif genes are not present in $K$. aerogenes.) In short, this region has been subject to considerable insertion or deletion during the evolutionary divergence of the enteric bacteria. It is tempting to note that $a s n V$ and $a s n U$ flank $n a c_{E}$ and present an 86-bp direct repeat. If no essential genes lie between these (as is seen for $E$. coli), simple deletion of the intervening region by asn $V$-asn $U$ recombination could lead to loss of $n a c$, but such a speculation remains untested.

In summary, E. coli has a nac gene that is a functional homolog of the nac gene from $K$. aerogenes, and this nac gene is probably involved in the nitrogen regulation of $E$. coli. The strong sequence conservation within the first 100 or so amino acids suggests an important role for the domain(s) in this region, whereas the large number of differences in the last 200 or so amino acids suggests that the domain(s) in this region are quite plastic and can withstand considerable amino acid substitution without loss of function.

\section{ACKNOWLEDGMENT}

This work was supported by Public Health Service grant GM 47156 from the National Institutes of Health to R.A.B.

\section{REFERENCES}

1. Ausubel, F., R. Brent, R. Kingston, D. Moore, J. Seidman, J. Smith, and K. Struhl (ed.). 1992. Current protocols in molecular biology. John Wiley \& Sons, Inc., New York, N.Y.

2. Backman, K., Y.-M. Chen, and B. Magasanik. 1981. Physical and genetic characterization of the $g \ln A-g \ln G$ region of the E. coli chromosome. Proc. Natl. Acad. Sci. USA 78:3742-3747.

3. Bender, R. A., P. M. Snyder, R. Bueno, M. Quinto, and B. Magasanik. 1983. Nitrogen regulation system of Klebsiella aerogenes: the nac gene. J. Bacteriol. 156:444-446.

4. Bender, R. A. 1991. The role of the NAC protein in the nitrogen regulation of Klebsiella aerogenes. Mol. Microbiol. 5:2575-2580.

5. Bender, R. A. 1996. Variations on a theme by Escherichia, p. 4-9. In F. C. Neidhardt, R. Curtis III, J. L. Ingraham, E. C. C. Lin, K. B. Low, B. Magasanik, W. S. Reznikoff, M. Riley, M. Schaechter, and H. E. Umbarger (ed.), Escherichia coli and Salmonella: cellular and molecular biology. American Society for Microbiology, Washington, D.C.

6. Best, E. A., and R. A. Bender. 1990. Cloning of the Klebsiella aerogenes nac gene, which encodes a factor required for nitrogen regulation of the histidine utilization (hut) operons in Salmonella typhimurium. J. Bacteriol. 172:70437048.

7. Brenchley, J. E., M. J. Prival, and B. Magasanik. 1973. Regulation of the synthesis of enzymes responsible for glutamate formation in Klebsiella aerogenes. J. Biol. Chem. 248:6112-6128.

8. Chen, L.-M., T. J. Goss, R. A. Bender, and S. Maloy. 1998. Genetic analysis, using P22 challenge phage, of the nitrogen activator protein DNA-binding site in the Klebsiella aerogenes put operon. J. Bacteriol. 180:571-577.

9. Chen, Y.-M., K. Backman, and B. Magasanik. 1982. Characterization of a gene, $g \ln L$, the product of which is involved in the regulation of nitrogen utilization in Escherichia coli. J. Bacteriol. 150:214-220.

10. Chisolm, K. 1989. A convenient moderate-scale procedure for obtaining DNA from bacteriophage lambda. BioTechniques 7:21-24.

11. Churchward, G., D. Belin, and Y. Nagamine. 1984. A pSC101-derived plasmid which shows no sequence homology to other commonly used cloning vectors. Gene 31:165-171.

12. Devries, B. E., C. K. Raymond, and R. Ludwig. 1984. Extension of bacteriophage lambda host range: selection, cloning, and characterization of a constitutive lambda receptor gene. Proc. Natl. Acad. Sci. USA 81:6080-6084.

13. Egner, C., and D. E. Berg. 1981. Excision of transposon Tn5 is dependent on the inverted repeats but not on the transposase function of Tn5. Proc. Natl. Acad. Sci. USA 78:459-463.

14. Feiss, M., S. Adhya, and D. L. Court. 1972. Isolation of plaque forming, galactose-transducing strains of phage lambda. Genetics 71:189-206.

15. Feng, J., T. J. Goss, R. A. Bender, and A. J. Ninfa. 1995. Activation of transcription initiation from the nac promoter of Klebsiella aerogenes. J. Bacteriol. 177:5523-5534.

16. Feng, J., T. J. Goss, R. A. Bender, and A. J. Ninfa. 1995. Repression of the Klebsiella aerogenes nac promoter. J. Bacteriol. 177:5335-5338.
17. Goldberg, R. B., R. A. Bender, and S. L. Streicher. 1974. Direct selection for P1-sensitive mutants of enteric bacteria. J. Bacteriol. 118:810-814.

18. Goldberg, R. B., F. R. Bloom, and B. Magasanik. 1976. Regulation of histidase synthesis in intergeneric hybrids of enteric bacteria. J. Bacteriol. 127: $114-119$.

19. Goss, T. J., and R. A. Bender. 1995. The nitrogen assimilation control protein, NAC, is a DNA binding transcription factor in Klebsiella aerogenes. J. Bacteriol. 177:3546-3555.

20. Henry, M. F., and J. E. Cronan. 1991. Direct and general selection for lysogens of Escherichia coli by phage recombinant clones. J. Bacteriol. 173: 3724-3732.

21. Janes, B. K., and R. A. Bender. 1998. Alanine catabolism in Klebsiella aerogenes: molecular characterization of the $d a d A B$ operon and its regulation by the nitrogen assimilation control protein. J. Bacteriol. 180:563-570.

22. Kohara, Y., K. Akiyama, and K. Isono. 1987. The physical map of the whole $E$. coli chromosome: application of a new strategy for rapid analysis and sorting of a large genomic library. Cell 50:495-508.

23. Lawrence, J. G., and J. R. Roth. 1995. The cobalamin (coenzyme $B_{12}$ ) biosynthetic genes of Escherichia coli. J. Bacteriol. 177:6371-6380.

24. Lowry, O. H., N. H. Rosebrough, A. L. Farr, and R. J. Randall. 1951. Protein measurement with the Folin phenol reagent. J. Biol. Chem. 193:265-275.

25. Macaluso, A., E. A. Best, and R. A. Bender. 1990. Role of the nac gene product in the nitrogen regulation of some NTR-regulated operons of Klebsiella aerogenes. J. Bacteriol. 172:7249-7255.

26. Magasanik, B. 1996. Regulation of nitrogen utilization, p. 1344-1356. In F. C. Neidhardt, R. Curtis III, J. L. Ingraham, E. C. C. Lin, K. B. Low, B. Magasanik, W. S. Reznikoff, M. Riley, M. Schaechter, and H. E. Umbarger (ed.), Escherichia coli and Salmonella: cellular and molecular biology. American Society for Microbiology, Washington, D.C.

27. Maniatis, T., E. F. Fritsch, and J. Sambrook. 1982. Molecular cloning: a laboratory manual. Cold Spring Harbor Laboratory, Cold Spring Harbor, N.Y.

28. Meers, J. L., D. W. Tempest, and C. M. Brown. 1970. Glutamine (amide): 2-oxoglutarate aminotransferase oxidoreductase (NADP), an enzyme involved in the synthesis of glutamate by some bacteria. J. Gen. Microbiol. 64:187-194.

29. Miller, J. H. 1972. Experiments in molecular genetics. Cold Spring Harbor Laboratory, Cold Spring Harbor, N.Y.

30. Morrison, D. A. 1977. Transformation in Escherichia coli: cryogenic preservation of competent cells. J. Bacteriol. 132:349-351.

31. Muller, W., W. Keppner, and I. Rasched. 1986. Versatile kanamycin-resistance cartridges for vector construction in E. coli. Gene 46:131-133.

32. Niki, H., T. Ogura, and S. Hiraga. 1990. Linear multimer formation of plasmid DNA in Escherichia coli hopE (recD) mutants. Mol. Gen. Genet. 224:1-9.

33. Osuna, R., B. K. Janes, and R. A. Bender. 1994. Roles of catabolite activator protein sites centered at -81.5 and -41.5 in the activation of the Klebsiella aerogenes histidine utilization operon hutUH. J. Bacteriol. 176:5513-5524.

34. Parada, J. L., and B. Magasanik. 1975. Expression of the hut operons of Salmonella typhimurium in Klebsiella aerogenes and in Escherichia coli. J. Bacteriol. 124:1263-1268.

35. Perez-Matos, A. E., and R. A. Bender. Unpublished data

36. Pomposiello, P. J., and R. A. Bender. 1995. Activation of the Escherichia coli lacZ promoter by the Klebsiella aerogenes nitrogen assimilation control protein (NAC), a LysR family transcription activator. J. Bacteriol. 177:48104824.

37. Prival, M. J., and B. Magasanik. 1971. Resistance to catabolite repression of histidase and proline oxidase during nitrogen-limited growth of Klebsiella aerogenes. J. Biol. Chem. 246:6288-6296.

38. Schauder, B., H. Blocker, R. Frank, and J. E. McCarthy. 1987. Inducible expression vectors incorporating the $E$. coli atpE translational initiation region. Gene 52:279-283.

39. Schell, M. A. 1993. Molecular biology of the LysR family of transcriptional regulators. Annu. Rev. Microbiol. 47:597-626.

40. Schwacha, A., and R. A. Bender. 1993. The product of the Klebsiella aerogenes nac (nitrogen assimilation control) gene is sufficient for activation of the hut operons and repression of the $g d h$ operon. J. Bacteriol. 175:21162124.

41. Schwacha, A., and R. A. Bender. 1993. The nac (nitrogen assimilation control) gene from Klebsiella aerogenes. J. Bacteriol. 175:2107-2115.

42. Simons, R. W., F. Houman, and N. Kleckner. 1987. Improved single and multicopy lac-based cloning vectors for protein and operon fusions. Gene 53:85-96.

43. Spratt, B. G., P. J. Hedge, S. te Hessen, A. Edelman, and J. K. BrommeSmith. 1986. Kanamycin-resistant vectors that are analogues of plasmids pUC8, pUC9, pEMBL8, and pEMBL9. Gene 41:337-342.

44. Tartoff, K. D., and C. A. Hobbs. 1987. Improved media for growing plasmid and cosmid clones. Focus 9:12.

45. Tyler, B. 1978. Regulation of the assimilation of nitrogen compounds. Annu. Rev. Biochem. 47:1127-1162. 